\title{
Enkele bespiegelingen over (juridische) regulering en instrumenten om maatschappelijk verantwoord ondernemen na te streven
}

\author{
O.R.J.C. Freens \& H. Koster
}

\section{Inleiding}

De aandacht voor maatschappelijk verantwoord ondernemen (MVO) is de laatste jaren sterk toegenomen. $\mathrm{MVO}^{1}$ ziet op thema's als mensenrechten, milieu, arbeidsomstandigheden, consumentenaangelegenheden, gemeenschapsontwikkeling en eerlijk zakendoen. ${ }^{2}$ In 1970 stelde Milton Friedman dat 'the social responsibility of business is to increase its profits'. ${ }^{3}$ Bescherming van menselijke en maatschappelijke belangen zou een taak zijn voor de overheid. Die gedachte gaat anno 2018 niet meer op. Voor Nederlandse ondernemingen wordt MVO een steeds belangrijker aandachtsgebied. Voorts is ook de aandacht (en druk) van het publiek en de overheid - mede in hoedanigheid van wetgever - met betrekking tot MVO aan het toenemen. MVO gaat erover dat ondernemingen bij hun streven naar winst rekening dienen te houden met menselijke en maatschappelijke belangen. Ondernemingen hebben aldus bepaalde verantwoordelijkheden op het terrein van MVO. In de praktijk zullen de culturele en ethische achtergronden van ondernemingen ervoor zorgen dat zij MVO op een manier inkleuren die op hun belangen en prioriteiten aansluit. ${ }^{4}$ Deze belangen en prioriteiten kunnen per onderneming verschillen. Van belang is voorts dat MVO uitgaat van een multistakeholderperspectief. Ondernemingen hebben niet slechts verantwoordelijkheden tegenover aandeelhouders, maar ook jegens andere stakeholders, zoals werknemers, klanten en toeleveranciers. MVO houdt in dat van ondernemingen wordt verwacht dat zij op vrijwillige basis een evenwicht vinden tussen hun economische en sociale verantwoordelijkheden, terwijl in het kader van besluitvorming rekening wordt gehouden met de belangen van alle stakeholders. In de vorige Nederlandse Corporate Governance Code was in de principes II.1 en III.1 bepaald dat het bestuur en de raad van commissarissen bij de vervulling van de taken de voor de onderneming relevante maatschappelijke aspecten van ondernemen

1 Voor het thema maatschappelijk verantwoord ondernemen worden wereldwijd verschillende aanduidingen gehanteerd: internationaal als corporate social responsibility (CSR), in het Verenigd Koninkrijk als corporate responsibility, in de Verenigde Staten als corporate citizenship en in Nederland als MVO.

2 T.E. Lambooy, Corporate social responsibility. Legal and semi-legal frameworks supporting CSR (diss. Leiden; Uitgaven vanwege het Instituut voor Ondernemingsrecht, nr. 77), Deventer: Kluwer 2010, p. 6.

3 M. Friedman. 'The social responsibility of business is to increase its profits', The New York Times Magazine 13 september 1970.

4 Lambooy 2010, p. 9-11. 
betrekken. Dit is in de huidige Code vervallen, omdat de Monitoring Commissie Corporate Governance Code MVO niet als een afzonderlijk na te streven doel beschouwt, maar als een integraal onderdeel van de dagelijkse bedrijfsvoering van een vennootschap die zich richt op langetermijnwaardecreatie. Daarbij dient er aandacht te zijn voor kansen en risico's en worden in dat kader de belangen van alle bij de onderneming betrokken stakeholders meegewogen. Aldus wordt MVO aangemerkt als integraal onderdeel van goed ondernemingsbestuur. MVO is ook in internationaal perspectief van groot belang, mede omdat ondernemingen in andere landen tegen andere regels, normen, gebruiken en culturen kunnen aanlopen. Dit roept de vraag op hoe MVO thans wordt gereguleerd en welke (juridische) instrumenten onder andere (kunnen) worden gehanteerd om te voldoen aan maatschappelijke verwachtingen ten aanzien van MVO. In verband daarmee kan voorts worden afgevraagd in hoeverre de toepassing van deze instrumenten (juridisch) kan worden afgedwongen en of aanpassing vereist is. ${ }^{5}$ In deze bijdrage beantwoorden wij deze vragen. ${ }^{6}$ Wij sluiten af met enkele conclusies.

\section{Regulering van het MVO-normenkader}

\subsection{Enkele achtergronden}

In het kader van MVO zijn drie verschillende dimensies van belang die tezamen worden aangeduid als de Triple-P, ofwel: Planet, People, Profit. ${ }^{7}$ Volgens deze theorie hebben ondernemingen niet slechts de verantwoordelijkheid om winst te maken (Profit), maar ook om dat te doen op een duurzame manier, waarbij op evenwichtige wijze de belangen van de maatschappij (People) en het milieu (Planet) tot hun recht komen. ${ }^{8}$ Enerzijds valt onder Planet de bescherming van de natuur en het milieu - water, bodem en lucht - en anderzijds de uitputting van natuurlijk hulpbronnen. ${ }^{9}$ Aangezien ondernemingsactiviteiten van multinationale ondernemingen (MNO's) omvangrijke schade toe kunnen brengen door de

5 In dat kader is ook van belang dat sprake kan zijn van een 'governance gap' of 'reguleringsvacuüm'. Multinationale ondernemingen hebben veelal te maken met een lappendeken van verschillende wetgeving en normenstelsels die internationale ondernemingsactiviteiten bestrijken, waardoor in sommige situaties multinationale ondernemingen (deels) niet onder het nationale gezag van de desbetreffende staten vallen. Zie hierover ook L.F.H. Enneking e.a., Zorgplichten van Nederlandse ondernemingen inzake internationaal maatschappelijk verantwoord ondernemen. Een rechtsvergelijkend en empirisch onderzoek naar de stand van het Nederlandse recht in het licht van de UN Guiding Principles, Den Haag: Boom juridisch 2016, p. 62-63.

6 Wij hebben ervoor gekozen om niet in te gaan op de functie die het aansprakelijkheidsrecht in dit kader kan vervullen. Dit omdat hierover reeds het nodige is geschreven. Zie hierover bijv. uitgebreid L.F.H. Enneking, Foreign direct liability and beyond - Exploring the role of tort law in promoting international corporate social responsibility and accountability, Den Haag: Eleven International Publishing 2012.

7 A.J.A.J. Eijsbouts \& B. Kemp, 'Over maatschappelijk verantwoord ondernemen, waardecreatie, ondernemingsrecht en vennootschappelijk belang', TvOB 2012, afl. 5, p. 121.

8 C. van Woensel, 'The framework of CSR', in: A.G. Castermans \& C. van Woensel (red.), CSR for young business lawyers, Den Haag: Eleven International Publishing 2017, p. 88-89.

9 A.J.A.J. Eijsbouts e.a., Maatschappelijk verantwoord ondernemen (Handelingen Nederlandse Juristen Vereniging 2010-1), Deventer: Kluwer 2010, p. 20. 
uitputting van natuurlijke hulpbronnen, verontreiniging van de bodem, aantasting van de ozonlaag door emissie van giftige stoffen en het stimuleren van overconsumptie, ${ }^{10}$ worden zij naast overheden in meerdere mate opgeroepen tot milieubewuster ondernemen. ${ }^{11}$ De tweede P, People, verwijst naar de sociale dimensie van MVO. Het gaat daarbij niet alleen om de machtsverhouding tussen ondernemingen en hun werknemers, maar ook om de zorg die ondernemingen dragen voor toeleveranciers en andere mensen die een rol hebben in de bedrijfstak waarop de onderneming invloed kan uitoefenen. ${ }^{12}$ Mensenrechten vormen een belangrijke categorie. Vraagstukken over onder andere minimumloon, veiligheid, het vermijden van discriminatie op de werkplek, de mogelijkheid om vakbonden op te richten en het bestrijden van slavernij en kinderarbeid zijn vaak onderdeel van discussie binnen deze dimensie. ${ }^{13}$ Met de $\mathrm{P}$ van Profit wordt ten slotte de zorg voor de continuïteit van de onderneming aangeduid. Een onderneming is een samenwerkingsverband dat primair is gericht op langetermijnwaardecreatie voor diens deelnemers. ${ }^{14}$ Het maken van winst vormt daarin een cruciaal onderdeel. Vanuit een MVO-perspectief is het van belang dat het genereren van winst niet ten koste gaat van rechtmatige belangen van derden, waaronder People en Planet.

Vragen naar het bestaan, de strekking en de omvang van verantwoordelijkheden voor ondernemingen op het terrein van MVO - in een globaliserende omgeving, die bovendien continu aan veranderingen blootstaat - zijn niet eenvoudig te beantwoorden. Waar interpretatie en incorporatie van MVO eerst werd beschouwd als een zaak die zo veel mogelijk aan ondernemingen zelf moest worden overgelaten, blijkt nu dat externe sturing of coördinatie wenselijk is en soms zelfs noodzakelijk. ${ }^{15}$ Verschillende actoren met vergelijkbare belangen ten aanzien van het creëren van MVO, waaronder overheden en supranationale organisaties, hebben bijgedragen aan het inkaderen van MVO door verschillende internationale richtlijnen en gedragscodes voor de private sector op te stellen. Deze richtlijnen en gedragscodes uiten zich als normenkaders die de legitieme verwachtingen van de (internationale) gemeenschap uitdrukken, en geven aan wat gewenst (internationaal) ondernemingsgedrag is en wat de minimumvereisten van (internationaal) maatschappelijk verantwoord gedrag zijn. ${ }^{16}$ Ook zijn er verschillende verschijningsvormen: ongeschreven normen, zelfregulering, soft law en hard law.

\subsection{Internationaal MVO-kader}

Van de vele internationale MVO-initiatieven die zich hebben ontwikkeld, worden inmiddels ruim 200 normenstelsels, gedragscodes en auditprotocollen wereldwijd p. 32.

11 Eijsbouts e.a. 2010, p. 21.

12 Eijsbouts e.a. 2010.

13 Lambooy 2010, p. 53.

14 Eijsbouts e.a. 2010, p. 22.

15 Enneking e.a. 2016, p. 64-65.

16 Eijsbouts e.a. 2010, p. 16. 
toegepast. ${ }^{17}$ Daarnaast kunnen wereldwijd bijna 400 instrumenten voor duurzaamheidsverslaggeving worden geteld. ${ }^{18}$ Uit onder andere een onderzoek van de Europese Commissie (EC) naar verwijzingen door grote Europese ondernemingen in hun verslaggeving naar internationale richtlijnen en gedragscodes blijkt dat een aantal hiervan internationaal een gezaghebbende rol heeft verkregen. ${ }^{19}$ Deze internationale richtlijnen en gedragscodes hebben gemeen dat zij doorgaans bindend zijn voor daarbij aangesloten lidstaten, maar eventuele aanvaarding daarvan door ondernemingen is in de regel gebaseerd op zelfbinding en voor hen dus vrijwillig. Zij kunnen daarom worden gekwalificeerd als instrumenten van soft law: een verzameling van gedragsregels die zijn ondergebracht in juridisch niet-bindende instrumenten, die desalniettemin (indirect) bepaalde juridische effecten kunnen hebben, en zijn gericht op praktische effecten. ${ }^{20}$ De internationale richtlijnen en gedragscodes schrijven niet slechts bepaalde te volgen processen voor - die zich voornamelijk lijken te focussen op verslaggeving en transparantie betreffende $\mathrm{MVO}^{21}$-, maar hebben in veel gevallen ook een normerend effect, aangezien in een aantal gevallen sancties kunnen volgen voor het niet-naleven van een richtlijn of gedragscode. Het normerend effect van deze internationale richtlijnen en gedragscodes heeft eraan bijgedragen dat deze inmiddels een gezaghebbende rol hebben verkregen en als inspiratie - en zelfs basis - dienen voor ondernemingen, branches, industriegroepen en overheden bij het opstellen van MVO-regulering en MVO-beleid. ${ }^{22}$ Wij noemen de belangrijkste internationale richtlijnen en gedragscodes.

17 Zie de ITC Standards Map voor een overzicht van MVO-initiatieven, beschikbaar op www. standardsmap.org/identify, geraadpleegd op 6 maart 2018.

18 KPMG, Global reporting initiative, United Nations Environment Programme, and University of Stellenbosch Business School Centre for Corporate Governance in Africa, Carrots \& sticks: Global trends in sustainability reporting regulation and policy, 2016, beschikbaar op https://home. kpmg.com/xx/en/home/insights/2016/05/carrots-and-sticks-global-trends-in-sustainabilityreporting-regulation-and-policy.html. Zie ook www.reportingcsr.org/home-p-1.html, beide geraadpleegd op 6 maart 2018.

19 EC, An analysis of policy references made by large EU companies to internationally recognised CSR guidelines and principles (Europese Commissie 1 maart 2013), beschikbaar via https://ec. europa.eu/docsroom/documents/10372/attachments/1/translations/en/renditions/pdf, geraadpleegd op 6 maart 2018; zie ook M. Aluchna \& S.O. Idowu, The dynamics of corporate social responsibility: A critical approach to theory and practice, Basel: Springer International Publishing Switzerland 2017, p. 277.

20 L. Senden, 'Soft law, self-regulation and co-regulation in European law: Where do they meet?', Electronic Journal of Comparative Law 2005, afl. 1, p. 23.

21 Van Woensel 2017, p. 98.

22 A. Okoye, Legal approaches and corporate social responsibility: Towards a Llewellyn's law-jobs approach, Abingdon: Routledge 2017, p. 131. 
De eerste betreft de United Nations Guiding Principles on Business and Human Rights. ${ }^{23}$ De UN Guiding Principles zijn gegrond op drie pijlers die voortvloeien uit het Ruggie Framework. ${ }^{24}$ Dit zijn:

1 Staten zijn verplicht om te beschermen tegen bedrijfsgerelateerde mensenrechtenschendingen (duty to protect).

2 Ondernemingen hebben de verantwoordelijkheid om negatieve gevolgen van de door of voor hen verrichte activiteiten op de mensenrechten van derden te voorkomen, beperken en verhelpen (duty to respect).

3 De noodzaak tot effectief herstel en/of verhaal voor slachtoffers van bedrijfsgerelateerde mensenrechtenschendingen (duty to remedy). ${ }^{25}$

De UN Guiding Principles bevatten normen die gelden voor zowel alle VN-lidstaten als ondernemingen, ongeacht soort, sector, locatie, structuur of grootte. ${ }^{26}$ Deze normen schrijven geen 'harde' juridische verplichtingen voor. Het uitgangspunt van de UN Guiding Principles is dat ondernemingen zelfstandig en vanuit hun duty to respect verantwoordelijkheid dragen, niet alleen voor het beoordelen of ondernemingsactiviteiten risico's op mensenrechtenschendingen opleveren, maar ook, in het verlengde daarvan, voor het voorkomen van negatieve impact die de eigen ondernemingsactiviteiten op mensenrechtengebied kunnen veroorzaken. ${ }^{27}$ Concreet betekent dit dat van ondernemingen wordt verwacht dat zij (1) hun commitment aan deze verantwoordelijkheid vastleggen in een beleidsverklaring, (2) overgaan tot een due diligence-procedure op mensenrechtengebied om de impact die hun ondernemingsactiviteiten op mensenrechten hebben in kaart te brengen, en (3) in gevallen waarin blijkt dat ondernemingsactiviteiten negatieve impact hebben op mensenrechten, procedures hebben voor het verhelpen van de negatieve gevolgen die zijn veroorzaakt of in de hand zijn gewerkt door de ondernemingsactiviteiten. ${ }^{28}$ Een belangrijk onderdeel van de UN Guiding Principles is dat de doelstelling onder de tweede pijler, namelijk het tot stand brengen van een beleid dat invulling geeft aan de verantwoordelijkheid die ondernemingen hebben om mensenrechten te eerbiedigen, volgens de UN Guiding Principles bereikt wordt door middel van een human rights due diligence-proces. Door middel van een human rights due diligence raakt de onderneming op de hoogte van de negatieve impact die zij heeft op mensenrechten en kan zij de negatieve gevolgen

Guiding Principles on Business and Human Rights: Implementing the United Nations 'Protect, Respect and Remedy' Framework, Report of the Special Representative of the Secretary-General on the issue of human rights and transnational corporations and other business enterprises, A/HRC/17/31 (21 maart 2011), beschikbaar via www.ohchr.org/Documents/Publications/ GuidingPrinciplesBusinessHR_EN.pdf, geraadpleegd op 7 maart 2018.

24 J.G. Ruggie, Protect, respect and remedy: A framework for business and human rights, Report of the Special Representative of the Secretary-General on the issue of human rights and transnational corporations and other business enterprises (7 april 2008), UN Doc A/HRC/8/5. UN Guiding Principles, p. 1. Zie hierover uitgebreid Enneking e.a. 2016, p. 64-75.

UN Guiding Principles, p. 1.

H. Koster, 'Maatschappelijk verantwoord ondernemen en de UN Guiding Principles on Business and Human Rights', Bb 2017/76, p. 250.

Enneking e.a. 2016, p. 19-20. 
aanpakken. ${ }^{29}$ Daarmee kan worden voorkomen dat maatregelen pas worden genomen bij geconstateerde misstanden en incidenten, wat vaak ook gepaard gaat met hoge kosten. ${ }^{30}$ De human rights due diligence die de UN Guiding Principles voorschrijven, geeft daartoe concrete aanwijzingen in de vorm van beleidsmaatregelen en procedures. Deze bestrijken mensenrechten, arbeidsrechten, het milieu en omkoping, thema's die volgens de UN Guiding Principles op de agenda van elke onderneming zouden moeten staan. ${ }^{31}$

Een tweede relevante code betreft de ILO Tripartite Declaration of Principles concerning Multinational Enterprises and Social Policy (ILO Declaration). ${ }^{32}$ De International Labour Organisation (ILO) is een van de eerste internationale organisaties die een platform biedt voor overheden, werkgevers en werknemers, met als doel, kort gezegd, het verbeteren van wenselijk gedrag van ondernemingen op het gebied van arbeid en sociaal beleid. ${ }^{33}$ Ten aanzien van het onderwerp fundamentele arbeidsrechten is de ILO belangrijk geweest voor de ratificatie door lidstaten van verschillende ILO-conventies. Deze conventies zijn samengevoegd in de op (met name) MNO's gerichte ILO Declaration. ${ }^{34}$ De ILO Declaration biedt verschillende aanbevelingen voor het op de juiste manier inrichten van aspecten waarop deze fundamentele arbeidsrechten betrekking hebben, waaronder opleidingsmogelijkheden en werk- en leefomstandigheden.

Een derde code die wij noemen, zijn de United Nations Global Compact Principles. ${ }^{35}$ Het UN Global Compact bevat tien beginselen, de 'Ten Principles', die van MNO's verlangen dat zij bepaalde kernwaarden opnemen op het gebied van men-

29 J.J. Wubbels, 'Wat kunnen we doen aan de remmende werking van het mededingingsrecht op duurzaamheidsinitiatieven?', M\&M 2016, afl. 5, p. 194.

30 Maatschappelijk verantwoord ondernemen loont (beleidsbrief van de minister voor Buitenlandse Handel en Ontwikkelingssamenwerking en de minister van Economische Zaken), bijlage bij Kamerstukken II 2012/13, 26485, 164, p. 4.

31 Van Woensel 2017, p. 89.

32 ILO, Tripartite Declaration of Principles concerning Multinational Enterprises and Social Policy, Fifth Edition, 2017; het tripartiet is samengesteld uit regeringsvertegenwoordigers van de 187 lidstaten van de ILO en voor elk land een lid namens de nationale werkgevers- en werknemersorganisaties. Een gewijzigde versie van de ILO Declaration is in maart 2017 verschenen, beschikbaar op www.ilo.org/global/about-the-ilo/newsroom/news/WCMS_547615/lang--en/index.htm, geraadpleegd op 8 maart 2018.

33 P.F. van der Heijden, 'De ILO: struikelend op weg naar de 100', TRA 2017/36, p. 3.

34 Het gaat om het recht op verenigingsvrijheid (Conventie 87) en collectief onderhandelen (Conventie 98), het verbod van kinderarbeid (Conventies 138 en 182), het verbod van dwangarbeid (Conventies 29 en 105) en het verbod van discriminatie op de werkplek (Conventies 100 en 111). Zie Van der Heijden 2017, p. 4.

35 Het UN Global Compact is afgeleid van de Universele Verklaring van de Rechten van de Mens, de ILO Declaration, The Rio Declaration on Environment and Development en The United Nations Convention Against Corruption. Zie https://www.unglobalcompact.org, geraadpleegd op 8 maart 2018. 
senrechten, het milieu, fundamentele arbeidsrechten en anticorruptie. ${ }^{36}$ Het initiatief is gebaseerd op zelfbinding en richt zich tot zowel commerciële als nietcommerciële ondernemingen. Van de aangesloten ondernemingen wordt verwacht dat zij verklaringen afleggen en jaarlijks in de vorm van een zogenaamde 'Communication on Progress' (COP) rapporteren over de vooruitgang die zij hebben geboekt bij de implementatie van de Ten Principles in de ondernemingsstrategie. ${ }^{37}$ Het initiatief lijkt succesvol, nu er ruim 9500 bedrijven uit meer dan 160 landen ingeschreven staan. ${ }^{38}$

Een vierde relevante internationale code betreft de OECD Guidelines for Multinational Enterprises. ${ }^{39}$ De OECD Guidelines maken duidelijk wat overheden van de landen die zijn aangesloten bij de OECD van MNO's verwachten op het gebied van MVO. De OECD Guidelines bieden in elf verschillende hoofdstukken handvatten voor MNO's om met MVO-thema's, die vergelijkbaar zijn met de kernthema's uit het UN Global Compact, maar een breder scala aan MVO-gerelateerde thema's bevatten, om te gaan. ${ }^{40}$ De OECD Guidelines zijn de enige door overheden onderschreven MVO-richtlijnen en het enige kader dat een geschillenbeslechtingssysteem bevat. ${ }^{41}$ Daarmee vormen zij voor verschillende overheden, waaronder de Nederlandse, het uitgangspunt voor internationaal MVO-beleid. ${ }^{42}$ Aangesloten lidstaten worden verplicht tot de oprichting van een Nationaal Contact Punt (NCP). Op het moment dat ondernemingen zich hebben gecommitteerd aan de OECD Guidelines, wordt van hen verwacht dat zij zakenrelaties, waaronder toeleveranciers en onderaannemers, al dan niet door middel van contractuele regelingen stimuleren $\mathrm{MVO}$-principes toe te passen die verenigbaar zijn met de OECD Guidelines. ${ }^{43}$ In geval van onhaalbare risicovermindering of de ernst van

36 Zie ook G. Argiolas, Social management. Principles, governance and practice, Basel: Springer International Publishing Switzerland 2014, p. 51; M.-J. van der Heijden, “'Supplier codes of conduct" en mensenrechten in een keten van contracten. Over enige vermogensrechtelijke implicaties van gedragscodes met betrekking tot mensenrechten en milieu in contractuele relaties', Contracteren 2011, afl. 1, p. 5.

37 UN Global Compact, zie https://www.unglobalcompact.org/participation/report, geraadpleegd op 8 maart 2018.

38 UN Global Compact, zie https://www.unglobalcompact.org/what-is-gc/participants, geraadpleegd op 8 maart 2018.

39 OECD, OECD Guidelines for Multinational Enterprises 2011; zie ook http://mneguidelines.oecd. org, geraadpleegd op 8 maart 2018.

40 Enneking e.a. 2016, p. 423; zie ook https://www.oesorichtlijnen.nl/oeso-richtlijnen/a/algemeneinformatie-oeso-richtlijnen, geraadpleegd op 8 maart 2018.

41 Zie de inleiding bij de Nederlandse vertaling van de OECD Guidelines, beschikbaar op https:// www.oesorichtlijnen.nl/documenten/publicatie/2014/12/8/oeso-richtlijnen-nederlandsevertaling, geraadpleegd op 8 maart 2018. Het geschillenbeslechtingssysteem is een van de twee hoofdtaken van het Nationaal Contact Punt. Dit Nationaal Contact Punt behandelt meldingen van personen, maatschappelijke organisaties en bedrijven die een meningsverschil hebben over de toepassing van de OESO-richtlijnen. Bij een melding staat het Nationaal Contactpunt de betrokken partijen bij om gezamenlijk tot een oplossing van het geschil te komen. Dit kan ook met behulp van een derde partij.

42 Zie https://www.oesorichtlijnen.nl/oeso-richtlijnen/o/oeso-richtlijnen, geraadpleegd op 8 maart 2018.

43 OECD, OECD Guidelines for Multinational Enterprises 2011, p. 25. 
een ongunstig effect zouden ondernemingen als laatste toevlucht moeten besluiten tot het stopzetten van de zakelijke relatie. ${ }^{44}$

De vijfde code betreft de International Standard for Social Responsibility (ISO 26000). ISO 26000 is de internationale standaard voor implementatie van MVO in een onderneming. Deze biedt ondernemingen een stappenplan voor het identificeren van stakeholders en het voeren van dialoog met deze stakeholders, het formuleren van prioriteiten en doelstellingen en het implementeren van MVO in de ondernemingsstrategie en -processen. ${ }^{45}$ Een aangesloten onderneming kan een zelfverklaring plaatsen op een publicatieplatform over de voortgang. ${ }^{46}$

De zesde en laatste code zijn de Global Reporting Initiative Guidelines and Standards (GRI Standards). Dit is de internationale standaard voor MVO-verslaggeving. ${ }^{47}$ Meer dan twee derde van de ondernemingen wereldwijd die rapporteren, gebruiken inmiddels de GRI Standards. ${ }^{48}$ De GRI Standards bestaan uit principes voor het bepalen van de inhoud van verslaggeving rondom de thema's economie (GRI 200), milieu (GRI 300) en maatschappij (GRI 400). ${ }^{49}$ De GRI Standards zijn ontworpen voor elk soort onderneming en moeten dienen als een algemeen aanvaard systeem dat ondernemingen helpt transparant te zijn door op kwalitatief hoog niveau te rapporteren over de impact die hun ondernemingsactiviteiten hebben op de economie, het milieu en de maatschappij en de positieve en negatieve resultaten die daaromtrent zijn geboekt.

\subsection{Europees MVO-kader}

De EC heeft zich als doel gesteld te bevorderen dat internationaal erkende richtlijnen en gedragscodes in het MVO-beleid van ondernemingen worden geïntegreerd. ${ }^{50}$ Als gevolg van de normen en procedures die hun grondslag hebben in deze internationale richtlijnen en gedragscodes is soft law de norm en staat de EC overwegend afwijzend tegenover dwingendrechtelijke rechtsregels en (verplicht)

44 OECD, OECD Guidelines for Multinational Enterprises 2011, p. 25.

45 Zie ook https://mvonederland.nl/iso-26000/wat-is-iso-26000, geraadpleegd op 8 maart 2018.

46 In Nederland kan een onderneming een zelfverklaring plaatsen op het publicatieplatform van NEN, zie https://www.nen.nl/NEN-Shop/Nieuws-over-ISO-26000-duurzaamheid/Regelhulp-ISO -26000-abonnement.htm, geraadpleegd op 8 maart 2018.

47 Beschikbaar op https://www.globalreporting.org/standards, geraadpleegd op 8 maart 2018.

48 EY, Value of Sustainability Reporting, 2016, p. 4, beschikbaar op www.ey.com/us/en/services/ specialty-services/climate-change-and-sustainability-services/value-of-sustainability-reporting, geraadpleegd op 8 maart 2018.

49 De GRI G4 Sustainability Reporting Guidelines zijn overgegaan in de GRI Sustainability Reporting Standards. Vanaf 1 juli 2018 moeten de GRI Standards de GRI G4 volledig vervangen, zie https://www.globalreporting.org/information/g4/Pages/default.aspx, geraadpleegd op 8 maart 2018.

50 EC, 'Een vernieuwde EU-strategie 2011-2014 ter bevordering van maatschappelijk verantwoord ondernemen', $\operatorname{COM}(2011) 681$, p. 15-16. 
toezicht. ${ }^{51}$ Er is echter wel een ontwikkeling zichtbaar in Europese regelgeving die, met name ten aanzien van MVO-verslaggeving, aan ondernemingen steeds meer verplichtingen oplegt. Daarnaast zijn er verschillende richtlijnen, verordeningen en besluiten die een MVO-connectie kennen. Genoemd kunnen worden:

1 EU Verordening inzake het Eco-Management and Audit Scheme ('EMAS-verordening'); ${ }^{52}$

2 EU Emissions Trading System (EU ETS); ${ }^{53}$

3 Richtlijn 2003/51/EC (Richtlijn Modernisatie); ${ }^{54}$

4 Europees Pollutant Release and Transfer Register (E-PRTR); ${ }^{55}$

5 Richtlijn 2012/27/EU (Richtlijn Energie-efficiëntie); ${ }^{56}$

6 Verordening (EU) 995/2010 (Houtverordening); ${ }^{57}$

7 Richtlijn 2009/49/EC (Bepaalde informatieverplichtingen en verplichting geconsolideerde jaarrekening); ${ }^{58}$

8 Verordening (EC) 1907/2006 ('REACH-verordening'); 59

9 Richtlijn 2014/95/EU (Richtlijn NFI). ${ }^{60}$

51 Van Woensel 2017, p. 97; M.T. Kamminga, 'Maatschappelijk verantwoord ondernemen: afdwingbaar via het internationale recht?', in: J.J.A. Hamers, C.A. Schwarz \& B.T.M. Steins Bisschop (red.), Noodzaak, plicht of wenselijkheid van Maatschappelijk Verantwoord Ondernemen, Den Haag: Boom Juridische uitgevers 2005, p. 65.

52 Verordening (EG) 1221/2009 van het Europees Parlement en de Raad van 25 november 2009 inzake de vrijwillige deelneming van organisaties aan een communautair milieubeheer- en milieuauditsysteem (EMAS), tot intrekking van Verordening (EG) 761/2001 en van de Beschikkingen 2001/681/EG en 2006/193/EG van de Commissie.

53 Zie https://ec.europa.eu/clima/policies/ets_nl, geraadpleegd op 9 maart 2018.

54 Richtlijn 2003/51/EC van het Europees Parlement en de Raad van 18 juni 2003 tot wijziging van de Richtlijnen 78/660/EEG, 83/349/EEG, 86/635/EEG en 91/674/EEG van de Raad betreffende de jaarrekening en de geconsolideerde jaarrekening van bepaalde vennootschapsvormen, banken en andere financiële instellingen, en verzekeringsondernemingen.

55 Zie ec.europa.eu/environment/industry/stationary/eper/legislation.htm, geraadpleegd op 9 maart 2018.

56 Richtlijn 2012/27/EU van het Europees Parlement en de Raad betreffende energie-efficiëntie, tot wijziging van de Richtlijnen 2009/125/EG en 2010/30/EU en houdende intrekking van de Richtlijnen 2004/8/EG en 2006/32/EG.

57 Verordening (EU) 995/2010 van het Europees Parlement en de Raad van 20 oktober 2010 tot vaststelling van de verplichtingen van marktdeelnemers die hout en houtproducten op de markt brengen.

58 Richtlijn 2009/49/EG van het Europees Parlement en de Raad van 18 juni 2009 tot wijziging van de Richtlijnen 78/660/EEG en 83/349/EEG van de Raad met betrekking tot bepaalde informatieverplichtingen van middelgrote ondernemingen en de verplichting een geconsolideerde jaarrekening op te stellen.

59 Verordening (EC) 1907/2006 van 18 december 2006 inzake de registratie en beoordeling van en de autorisatie en beperkingen ten aanzien van chemische stoffen (REACH), tot oprichting van een Europees Agentschap voor chemische stoffen, houdende wijziging van Richtlijn 1999/45/EG en houdende intrekking van Verordening (EEG) 793/93 van de Raad en Verordening (EG) 1488/94 van de Commissie alsmede Richtlijn 76/769/EEG van de Raad en de Richtlijnen 91/155/EEG, 93/67/EEG, 93/105/EG en 2000/21/EG van de Commissie.

60 Richtlijn 2014/95/EU van het Europees Parlement en de Raad van 22 oktober 2014 tot wijziging van Richtlijn 2013/34/EU met betrekking tot de bekendmaking van niet-financiële informatie en informatie inzake diversiteit door bepaalde grote ondernemingen en groepen. 


\subsection{Nationaal MVO-kader}

De rol die de nationale overheden, waaronder de Nederlandse, maar ook andere staten en internationale organisaties spelen, is doorgaans vooral ondersteunend en stimulerend van aard. ${ }^{61}$ Als gevolg daarvan staan zij overwegend afwijzend tegenover dwingendrechtelijke rechtsregels en (verplicht) toezicht. ${ }^{62}$ Deze benadering ligt ook ten grondslag aan de normen en procedures die onder andere de ILO, OESO en UN Global Compact voorschrijven in de eerdergenoemde gedragscodes. Aldus stellen overheden, waaronder de Nederlandse, over het algemeen geen verplichtingen voor het behalen van MVO-resultaten. ${ }^{63}$ Dat neemt niet weg dat er inmiddels op nationaal niveau een trend zichtbaar is van wetgevingsinitiatieven die ondernemingen steeds meer verplichten te rapporteren over MVO. ${ }^{64}$

\subsection{Tussenconclusie}

Er bestaan veel verschillende MVO-kaders op internationaal, Europees en nationaal niveau. De reikwijdte van deze initiatieven verschilt onderling sterk en ze leveren tezamen allerminst een eenduidig beeld op. ${ }^{65}$ Sommige initiatieven zijn algemeen van karakter en strekken zich uit over alle relevante aspecten, andere zijn beperkt tot specifieke regio's, industriesectoren of thema's. ${ }^{66}$ Daarnaast voorzien sommige initiatieven in praktische voorschriften, terwijl andere minimumstandaarden bevatten. Wat opvalt, is enerzijds dat actoren overwegend afwijzend staan tegenover dwingendrechtelijke regels en (verplicht) toezicht, en anderzijds dat op elk niveau - van internationaal tot nationaal - in de afgelopen jaren bijzonder veel initiatieven zijn genomen ter regulering van MVO, die juist meer verplichtingen aan ondernemingen opleggen, met name ten aanzien van MVO-verslaggeving.

61 'Maatschappelijk verantwoord ondernemen loont' (beleidsbrief van de minister voor Buitenlandse Handel en Ontwikkelingssamenwerking en de minister van Economische Zaken), bijlage bij Kamerstukken II 2012/13, 26485, 164, p. 3.

62 Kamminga 2005, p. 65.

63 Zwalve-Erades 2015, p. 43.

64 Gedacht kan worden aan de omzetting van de Richtlijn NFI via de besluiten 'bekendmaking nietfinanciële informatie' en 'bekendmaking diversiteitbeleid', verankerd in art. 2:391 lid 5 BW, en het wetsvoorstel zorgplicht kinderarbeid (Voorstel van wet van het lid Kuiken houdende de invoering van een zorgplicht ter voorkoming van de levering van goederen en diensten die met behulp van kinderarbeid tot stand zijn gekomen, Kamerstukken I 2016/17, 34506, A; gewijzigd voorstel van wet van 6 februari 2017). Zie ook https://mvonederland.nl/transparantie/trends-en -ontwikkelingen, geraadpleegd op 10 maart 2018.

65 Zie ook M.W. Scheltema, 'Assessing effectiveness of international private regulation in the CSR arena', in: M. Menting, J.B.M. Vranken \& M.W. Scheltema, Gedragscodes in internationaal, Europees en privaatrechtelijk perspectief (Preadviezen Nederlandse Vereniging voor Burgerlijk Recht 2013), Zutphen: Uitgeverij Paris 2014, p. 266.

66 K. Jesse, 'Bedrijven en het milieu: corporate environmental responsibility', in: J.M. Bazelmans e.a., Duurzame handel in juridisch perspectief, Den Haag: Boom Juridische uitgevers 2014, p. 8. 


\section{MVO-instrumenten in de praktijk en juridische afdwingbaarheid ervan}

\subsection{Drie MVO-instrumenten}

In deze paragraaf bespreken wij een drietal instrumenten die in de praktijk worden aangewend om MVO na te streven. Het betreft MVO-gedragscodes, IMVOconvenanten en transparantie. Wij zullen daarbij ook steeds ingaan op de juridische afdwingbaarheid van deze drie instrumenten en of aanpassing vereist is.

\subsection{De MVO-gedragscode}

Een eerste MVO-instrument dat genoemd kan worden, is een MVO-gedragscode. Dit betreft een vorm van zelfregulering die veelvuldig door ondernemingen op wereldwijde basis wordt benut ter versterking van de positie op MVO-gebied. ${ }^{67} \mathrm{Er}$ zijn verschillende soorten. Allereerst de ondernemingspecifieke gedragscodes, die zijn gericht op de eigen organisatie en op externe relaties, zoals zakelijke partners en leveranciers in de gehele handelsketen. ${ }^{68}$ Daarnaast zijn er gedragscodes die sectorspecifiek worden opgesteld. ${ }^{69}$ Ook zijn er gedragscodes die zich specifiek richten tot de werknemers van een onderneming. ${ }^{70}$ In veel gevallen verwijzen de ondernemings- en sectorspecifieke gedragscodes naar (sectoroverschrijdende) internationale gedragscodes zoals de OECD Guidelines. De onderneming legt dan zelf in de gedragscode vast aan welke regels zij zich wil houden. ${ }^{71}$ Het document schrijft voor wat de basisverantwoordelijkheden zijn die de onderneming heeft ten opzichte van haar stakeholders en omgeving, en welke (kern)waarden, normen of regels de onderneming in acht wil nemen. ${ }^{72}$ Daarbij gaat het steeds over het gedrag dat de onderneming dient te vertonen. Het instrument is nuttig voor zowel interne als externe communicatie over de zaken waar de onderneming zich hard voor wil maken. ${ }^{73}$

67 Inmiddels heeft in Nederland ruim 90\% van de grote vennootschappen een gedragscode, zie https://mvonederland.nl/bedrijfsethiek/bedrijfscodes-van-grote-bedrijven, geraadpleegd op 10 maart 2018.

68 Van der Heijden 2011, p. 5; A.L. Vytopil, Contractual control in the supply chain. On corporate social responsibility, codes of conduct, contracts and (avoiding) liability (diss. Utrecht), Den Haag: Eleven International Publishing 2015, p. 66.

69 Vrijwel elke industrie heeft een aparte code, zoals de textiel-, olie- en gas-, voedsel-, bank- en verzekerings-, houtkap-, metaal-, telecommunicatie- en diamantindustrie en het toerisme; zie ook Van der Heijden 2011, p. 4-5; M. Koelemeijer, 'Naar een Nederlandse gedragscode maatschappelijk verantwoord ondernemen?', in: J.J.A. Hamers, C.A. Schwarz \& B.T.M. Steins Bisschop (red.), Noodzaak, plicht of wenselijkheid van Maatschappelijk Verantwoord Ondernemen, Den Haag: Boom Juridische uitgevers 2005, p. 109.

70 Zie hierover uitgebreid D.J. Rutgers, 'IBA GEI Code of Conduct Report', Bb 2017/77, p. 253-256.

71 R.J. Hoff, 'De juridische aspecten van een bedrijfscode', Management Executive 2003, p. 8.

72 S.P. Kaptein, H.K. Klamer \& J.C.J. ter Linden, De integere organisatie, het nut van een bedrijfscode, Den Haag: Vereniging NCW 1999, p. 16; B. Baarsma e.a., Zelf doen? Inventarisatiestudie van zelfreguleringsinstrumenten (rapport nr. 664), Amsterdam: SEO Economisch Onderzoek 2003, p. 28; M. Menting \& J.B.M. Vrancken, 'Gedragscodes in een meergelaagd privaatrecht in Europa en Nederland', in: M. Menting, J.B.M. Vranken \& M.W. Scheltema, Gedragscodes in internationaal, Europees en privaatrechtelijk perspectief (Preadviezen Nederlandse Vereniging voor Burgerlijk Recht 2013), Zutphen: Uitgeverij Paris 2014, p. 46-47; Vytopil 2015, p. 64.

Koelemeijer 2005, p. 110 
De gedragscode wordt gekenmerkt door een vrijwillig karakter. ${ }^{74}$ Vrijwilligheid betekent niet zozeer dat ondernemingen zich niet aan een gedragscode hoeven houden, maar wel dat er over het algemeen geen juridische verplichting bestaat tot naleving van de gedragscode. ${ }^{75}$ Juridische binding ligt wel voor de hand in situaties waarin de overheid is betrokken, bijvoorbeeld wanneer (1) de overheid gedragscodes verplicht stelt en mede de inhoud ervan bepaalt door concreet voor te schrijven hoe ze tot stand komen en wat ze inhouden; (2) de gedragscode is goedgekeurd door de overheid of door één of meer daartoe aangewezen nationale of Europese instanties; (3) de gedragscode algemeen verbindend is verklaard; of (4) de gedragscode tot stand is gebracht door een branche in nauwe en gelijkwaardige samenwerking met de afnemers. ${ }^{76}$

Indien een onderneming op eigen initiatief een (interne) gedragscode opstelt, zal van juridische binding nauwelijks sprake kunnen zijn. Stakeholders kunnen de onderneming aanspreken op niet-naleving van de gedragscode, maar kunnen deze over het algemeen niet in rechte afdwingen. ${ }^{77}$ Het Nederlandse aansprakelijkheidsrecht is vooralsnog ontoereikend om tot aansprakelijkheid of tot een schadevergoeding te komen wegens het niet-naleven van de gedragscode. ${ }^{78}$ Het vrijwillige karakter van de gedragscode kan bovendien een knelpunt vormen voor de bevordering van MVO. De gedragscode kan namelijk slechts effect sorteren indien de ideologie uit de gedragscode daadwerkelijk wordt doorgevoerd, gestimuleerd en gehandhaafd. ${ }^{79}$ Het vrijwillige karakter brengt echter het risico met zich dat ondernemingen, kort gezegd, aan MVO kunnen 'doen' door simpelweg bepaalde MVO-doelen in de eigen gedragscode op te nemen, maar deze vervolgens links te laten liggen, zonder dat zij hierop juridisch succesvol aangesproken kunnen worden. Uit onderzoek blijkt dat dit in de praktijk veelvuldig voorkomt; de gedragscode wordt beschouwd als een praktisch probleem dat opgelost dient te worden. ${ }^{80}$ Dit maakt het juridisch interessant te bezien welke mogelijkheden er zijn om de gedragscode af te dwingen.

74 Vytopil 2015, p. 65.

75 Nederlands recht verplicht ondernemingen in beginsel niet tot het opstellen van een MVOgedragscode of tot het aanvaarden van een gedragscode opgesteld door een internationale organisatie, zoals codes van de koffiebranche, banken, kledingindustrie en het keurmerk FSC-hout. Zie ook T.E. Lambooy, 'De problematiek van het maatschappelijk verantwoord ondernemen en corporate governance', in: J.J.A. Hamers, C.A. Schwarz \& B.T.M. Steins Bisschop (red.), Maatschappelijk verantwoord ondernemen: Corporate social responsibility in a transnational perspective, Antwerpen: Intersentia 2005, p. 82.

76 Menting \& Vrancken 2014, p. 41.

77 De winst van waarden (SER-advies 00/11 van 15 december 2000 aan de staatssecretaris van Economische Zaken), Den Haag: SER 2000, p. 72; Van der Heijden 2011, p. 8.

78 A.L. Vytopil, 'MVO-gedragscodes, contracten en aansprakelijkheid van goede bedoelingen naar het beperken van aansprakelijkheidsrisico's', Contracteren 2015, afl. 3, p. 81; A.L. Vytopil, 'Zin en onzin van gedragscodes, contractenrecht en aansprakelijkheidsrecht voor het bevorderen van duurzaamheid in handelsketens', in: J.M. Bazelmans e.a., Duurzame handel in juridisch perspectief, Den Haag: Boom Juridische uitgevers 2014, p. 19.

79 Hoff 2003, p. 9; S.P. Kaptein \& H.K. Klamer, 'De bedrijfscode als effectief managementinstrument', Holland Management Review 2000/72, p. 25.

80 Zie ook Vytopil 2014, p. 19. 
Het is enerzijds afhankelijk van de aard en inhoud van de gedragscode en anderzijds van de manier waarop de onderneming met de gedragscode omgaat of en in hoeverre een belanghebbende rechtens een actie aan de regels van een gedragscode kan ontlenen, en het is voorts onzeker of en in hoeverre in de praktijk met succes een beroep kan worden gedaan op een gedragscode indien een betrokkene zich niet daaraan houdt. ${ }^{81}$ Een manier om werkelijk contractuele controle te krijgen over de handelsketen is bewerkstelligen dat de handelspartners de MVOgedragscode van de onderneming ondertekenen en vastleggen in één of meer contracten of algemene voorwaarden, al dan niet met eventuele andere MVO-maatregelen. ${ }^{82}$ Hierdoor wordt de vrijwillige gedragscode omgezet in een contractueel bindend instrument. Dergelijke integratie van de gedragscode in een contractueel beding, bijvoorbeeld in de vorm van een sustainability clause, komt in toenemende mate voor. ${ }^{83}$ Welke methode ook wordt gebruikt - verwijzing naar een ondernemingspecifieke, sectorspecifieke of internationale gedragscode, of een gedetailleerde clausule -, het moet helder zijn voor de contractspartij dat de gedragscode onderdeel van het aanbod is. ${ }^{84}$ Ondernemingen kunnen zo de contractspartij ertoe aanzetten zich aan de gedragscode te houden, en door middel van een kettingbeding opeenvolgende leveranciers in de handelsketen zich aan dezelfde gedragscode laten committeren. Ook kan de onderneming bedingen dat zij de contractspartij monitoren en sancties kan opleggen bij niet-naleving. Op deze manier ontstaat een web van contracten met checks and balances. ${ }^{85}$ Dit maakt het contract een uitstekend middel om de verantwoordelijkheden die de onderneming zichzelf heeft opgelegd in de gedragscode 'hard' te maken, voor zowel de onderneming als haar dochterondernemingen en handelspartners in de supply chain. Het vorenstaande neemt niet weg dat alhoewel het contractrecht over het algemeen een goed hulpmiddel kan zijn om MVO te bevorderen, de niet-naleving van de gedragscode in de regel (ook) consequenties kan hebben voor de maatschappelijke reputatie van de onderneming. ${ }^{86}$ Daarnaast is het bepaald niet ondenkbaar dat de 'commitments' die ondernemingen aangaan ten aanzien van MVO in het handelsverkeer zo gebruikelijk worden, dat zij verworden tot handelsgebruiken die volgens het internationaal commercieel contractrecht als bindend worden beschouwd. ${ }^{87}$

81 Koelemeijer 2005, p. 112-113; R.J.C. Galle, Ondernemen en ethiek, Den Haag: Boom Juridische uitgevers 2000, p. 91-92; Hoff 2003, p. 10.

82 A.L. Vytopil, 'Contractual control and labour-related CSR norms in the supply chain: Dutch best practices', Utrecht Law Review 2012, afl. 1, p. 64-70; A.G. Castermans, 'Corporations for human rights', European Company Law (7) 2010, afl. 5, p. 217.

83 Vytopil 2015, p. 64.

84 A.G. Castermans \& B. Fauvarque Cosson, 'CSR in contracts', in: A.G. Castermans \& C. van Woensel (red.), CSR for young business lawyers, Den Haag: Eleven International Publishing 2017, p. 127.

85 Van der Heijden 2011, p. 7.

86 Zie De winst van waarden (SER-advies 00/11 van 15 december 2000 aan de staatssecretaris van Economische Zaken), Den Haag: SER 2000, p. 72.

87 Zie ook Castermans \& Fauvarque Cosson 2017, p. 129. 


\subsection{IMVO-convenanten ${ }^{88}$}

Staten hebben op grond van de UN Guiding Principles een verplichting tot het beschermen (duty to protect) van mensenrechten. Er zijn verschillende manieren waarop de Nederlandse overheid hieraan probeert te voldoen. Op internationaal vlak doet zij dat niet alleen door met andere overheden in gesprek te gaan over MVO en ondernemingen via voorlichting duidelijk te maken welke risico's zij lopen met hun internationale ondernemingsactiviteiten, ${ }^{89}$ maar ook door financiele bijdragen te leveren ter bevordering van een effectief stelsel van internationale organisaties en prioritaire mensenrechtenthema's. ${ }^{90} \mathrm{Zo}$ is in Nederland naleving van de OECD Guidelines een voorwaarde om (financiële) overheidssteun te krijgen bij internationale handelsprojecten. ${ }^{91}$ Op basis van de vrij recent in werking getreden Europese aanbestedingsrichtlijnen ${ }^{92}$ stellen overheden voorts in het algemeen steeds vaker MVO-gerelateerde voorwaarden binnen aanbestedingsprocedures. ${ }^{93}$ Daarnaast nemen overheden stappen door MVO-samenwerkingen op langere termijn aan te gaan met ondernemingen, sectoren en maatschappelijke organisaties.

In dat kader is van belang dat Nederland na het Verenigd Koninkrijk het tweede land ter wereld is dat de voorwaarde van de UN Guiding Principles tot het opstellen van een nationaal actieplan in de praktijk heeft gebracht. ${ }^{94}$ Het Nationaal Actieplan Bedrijfsleven en Mensenrechten (hierna: het Nationaal Actieplan) zet uiteen op welke manieren de Nederlandse overheid voldoet aan haar duty to protect en hoe zij eerbiediging van mensenrechten door ondernemingen - in hun eigen ondernemingsactiviteiten en in de supply chain - tracht te ondersteunen en bevorderen. ${ }^{95}$ Het Nationaal Actieplan maakt duidelijk dat de Nederlandse over-

88 Afkorting van internationaal maatschappelijk verantwoord ondernemen.

89 Ondernemingen kunnen de door de overheid gefinancierde MVO Risico Checker gebruiken om inzichtelijk te krijgen welke MVO-risico's zij lopen, beschikbaar op www.mvorisicochecker.nl/nl, geraadpleegd op 11 maart 2018.

90 Kamerstukken II 2017/18, 34775 V, 1, p. 27-30 (Rijksbegroting 2018).

91 Zie https://www.rvo.nl/onderwerpen/internationaal-ondernemen/kennis-en-informatie/maat schappelijk-verantwoord-ondernemen, geraadpleegd op 12 maart 2018.

92 Zie de Europese Richtlijnen 2014/EU/24 voor overheidsopdrachten in klassieke sectoren, 2014/ EU/25 voor overheidsopdrachten in speciale sectoren en 2014/EU/26 voor concessies; zie ook https://www.rijksoverheid.nl/onderwerpen/aanbesteden/aanbesteden-internationaal, geraadpleegd op 12 maart 2018.

93 Het belang van aanbestedingen voor ondernemingen mag niet worden onderschat. De publieke sector in de EU is met een jaarlijks uitgavenpatroon van $€ 2100$ biljoen aan producten en diensten de grootste consument binnen de EU. Zie Commission Staff Working Paper, Evaluation report, 'Impact and effectiveness of EU public procurement legislation', SEC(2011)853.

94 Nationaal Actieplan Bedrijfsleven en Mensenrechten (brief van de minister van Buitenlandse Zaken van 3 januari 2014), bijlage bij Kamerstukken II 2013/14, 26485, 174; zie ook https:// www.rijksoverheid.nl/actueel/nieuws/2013/12/20/nationaal-actieplan-mensenrechten-enbedrijfsleven-knowing-en-showing, geraadpleegd op 12 maart 2018. Naast het Verenigd Koninkrijk en Nederland zijn er nu achttien andere landen met een Nationaal Actieplan en meerdere landen die bezig zijn met het opstellen van een Nationaal Actieplan, zie https://businesshumanrights.org/en/un-guiding-principles/implementation-tools-examples/implementation-bygovernments/by-type-of-initiative/national-action-plans, geraadpleegd op 12 maart 2018. Kamerstukken II 2013/14, 26485, 174, p. 5 (Nationaal Actieplan). 
heid van ondernemingen verwacht dat zij voldoen aan hun 'duty to respect'. Dat kunnen zij doen door rekenschap af te leggen over hun beleid en daarover in dialoog te gaan, bijvoorbeeld door overleg met belanghebbenden of via publieke rapportage. ${ }^{96}$ Zoals nader beschreven in paragraaf 2.2 , is het uitvoeren van een human rights due diligence volgens de UN Guiding Principles de juiste manier waarop ondernemingen inzicht kunnen krijgen in de impact die de ondernemingsactiviteiten hebben op mensenrechten, om daar vervolgens daadkrachtig op in te spelen. Indien de invloed van een onderneming groot genoeg is, zal de onderneming zelf de mogelijkheid hebben om misstanden te identificeren, aan te pakken en te voorkomen. Het is echter voor ondernemingen veelal moeilijk om dit op individuele basis te bewerkstelligen. Wanneer een individuele onderneming onvoldoende invloed heeft, problemen complexer en structureler worden en verder in de supply chain en maatschappij liggen, is samenwerking met andere partijen nodig. ${ }^{97}$

De Nederlandse overheid heeft ingezien dat als opmaat naar MVO-resultaten vergroting van invloed nodig was om Nederlandse ondernemingen een optimale due diligence te laten uitvoeren. Zodoende heeft zij, vanuit haar duty to protect en het Nationaal Actieplan, het initiatief genomen ondernemingen te helpen bij het identificeren van de sectoren waarin de grootste risico's op negatieve maatschappelijke scenario's bestaan. ${ }^{98}$ Door middel van deze 'Sector Risico Analyse' werden de 86 sectoren van de Nederlandse economie onderzocht en uiteindelijk 13 sectoren met de grootste risico's op het gebied van MVO geselecteerd: bouw, chemie, detailhandel, energie, financiële sector, groothandel, hout en papier, land- en tuinbouw, metaal, elektronica, olie en gas, textiel en kleding en voedingsmiddelen. ${ }^{99}$ Vervolgens heeft de Nederlandse overheid afspraken gemaakt met een aantal van de brancheorganisaties uit de internationaal opererende risicosectoren in de vorm van de zogenoemde 'Internationale MVO-convenanten' (IMVO-convenanten), ${ }^{100}$ onder andere over verdere uitwerking van een te volgen due diligenceproces. ${ }^{101}$ De vernieuwing van deze aanpak zit in het feit dat de IMVO-convenanten gaan over afspraken van één of meer sectoren uit de ondernemingswereld

96 Kamerstukken II 2013/14, 26485, 174, p. 29 (Nationaal Actieplan).

97 IMVO-convenanten (SER-advies 14/04 van april 2014 aan de minister voor Buitenlandse Handel en Ontwikkelingssamenwerking en de minister van Economische Zaken), Den Haag: SER 2014, p. 15.

98 Zie ook Wubbels 2016, p. 194; M. Reichwein \& J. van Wijngaarden, 'The love-hate relationship between lawmaking and CSR policy', in: A.G. Castermans \& C. van Woensel (red.), CSR for young business lawyers, Den Haag: Eleven International Publishing 2017, p. 197-198.

99 KPMG, MVO Sector Risico Analyse, 2014, p. 19.

100 Hierbij is aangesloten op de betekenis die de SER heeft gegeven aan het IMVO-convenant, zoals is uiteengezet in het SER-advies IMVO-convenanten 2014. Gezien de faciliterende rol die de SER heeft aangenomen bij de totstandkoming van de IMVO-convenanten, is de gedachte van de SER over het IMVO-convenant terug te vinden in de correspondentie van de overheid over IMVOconvenanten en andere (officiële) kanalen, zie bijv. https://www.internationalrbc.org/?sc_lang= nl, geraadpleegd op 14 maart 2018.

101 Het eerste IMVO-convenant Duurzame Kleding en Textiel werd op 4 juli 2016 ondertekend, zie https://www.ser.nl/nl/actueel/congressen/2016/20160704-imvo-kleding-textiel.aspx, geraadpleegd op 14 maart 2018. 
met één of meer andere partijen, zoals de overheid en stakeholders, om concrete problemen aan te pakken die ondernemingen op individuele basis niet (geheel) hadden kunnen oplossen. Nederland heeft een voortrekkersrol genomen met de convenantaanpak, die wereldwijd wordt beschouwd als innovatief. ${ }^{102}$

Een schets van de stand van zaken toont dat na het tekenen van het IMVO-convenant Verantwoord Goud op 19 juni 2017 het aantal convenanten op vijf is gekomen. ${ }^{103}$ Eerder werden de IMVO-convenanten voor Duurzame Kleding en Textiel, Bancaire Sector, Plantaardige Eiwitten en Bevorderen Duurzaam Bosbeheer afgesloten. ${ }^{104}$ Daarnaast is op 7 december 2017 binnen de natuursteensector een pilotproject van start gegaan, vooruitlopend op het sluiten van een IMVOconvenant over duurzame inkoop van natuursteen, ${ }^{105}$ en is de metallurgische sector onlangs gestart met onderhandelingen voor een IMVO-convenant. ${ }^{106}$ Een partij die zich heeft aangesloten bij een IMVO-convenant verplicht zich op vrijwillige basis tot het leveren van bepaalde resultaten en inspanningen. Dat maakt het IMVO-convenant een resultaatsverbintenis. Het uitvoeren van due diligence wordt als een eerste en noodzakelijke stap gezien voor het boeken van resultaten. ${ }^{107} \mathrm{De}$ doelstelling van de convenanten is tweeledig:

1 op specifieke risico's binnen een termijn van drie tot vijf jaar verbetering bereiken voor groepen die negatieve effecten ervaren; en

2 een gezamenlijke oplossing bieden voor problemen die ondernemingen zelf niet geheel op kunnen lossen. ${ }^{108}$

De IMVO-convenanten leveren spanning op met het mededingingsrecht. Er bestaat een reële kans dat partijen op grond van bijvoorbeeld het IMVO-convenant Duurzame Kleding en Textiel worden gestimuleerd afspraken te maken over leefbare lonen in de supply chain, en die lonen vervolgens doorberekenen in de verkoopprijs. Als ondernemingen een dergelijke (prijs)afspraak maken, lopen zij op grond van het mededingingsrecht het gevaar in strijd te handelen met het kartelverbod. ${ }^{109}$ De wetgever heeft zich gerealiseerd dat zich een spanningsveld heeft gevormd tussen IMVO-convenanten en het mededingingsrecht. De minister heeft zich er daarom toe aangezet voorbereidingen te treffen voor het wetsvoorstel ruimte voor duurzaamheidsinitiatieven. Het wetsvoorstel faciliteert partijen door

102 B.P. ter Haar, '(Weg)kijken? Nee, doorpakken!', TRA 2017/29, p. 33.

103 Zie ministeriële regeling van 3 juli 2017, Stcrt. 2017, 36871.

104 Zie ook https://www.rijksoverheid.nl/onderwerpen/internationaal-maatschappelijk-verantwoord -ondernemen-imvo/imvo-convenanten, geraadpleegd op 14 maart 2018.

105 Deze pilots hebben een looptijd van 2017 tot 2020. Zie hiervoor uitgebreid https://www. imvoconvenanten.nl/natuursteen?sc_lang=nl, geraadpleegd op 14 maart 2018.

106 Zie https:/www.imvoconvenanten.nl/nieuws/2018/3/metallurgische-industrie-verduurzamen? sc_lang=nl, geraadpleegd op 14 maart 2018.

107 Convenant Duurzame Kleding en Textiel, p. 15; Convenant Bancaire Sector, p. 14-17; Convenant Duurzaam Bosbeheer, p. 3; art. 4 Convenant Plantaardige Eiwitten; Convenant Verantwoord Goud, p. 2.

108 IMVO-convenanten (SER-advies 14/04 van april 2014 aan de minister voor Buitenlandse Handel en Ontwikkelingssamenwerking en de minister van Economische Zaken), Den Haag: SER 2014, p. 19.

109 Wubbels 2016, p. 193. 
hen in de toekomst de mogelijkheid te bieden de regering te vragen een duurzaamheidsinitiatief, zoals een IMVO-convenant, algemeen verbindend te verklaren. ${ }^{110}$

Bij het opstellen van de convenanten is aan de partijen de vrijheid gegeven afspraken te maken over de stappen die de partijen zouden moeten zetten wanneer afspraken niet worden nagekomen, en wanneer geschillen ontstaan over de voortgang of de resultaten. Niettemin geldt daarbij het algemene uitgangspunt dat partijen elkaar in goed vertrouwen kunnen aanspreken op elkaars handelen. ${ }^{111}$ Zodoende is het aangaan van een dialoog in beginsel de voorgeschreven manier van geschilbeslechting. In het verlengde daarvan zijn in elk huidig convenant klacht- en geschilbeslechtingsmechanismen opgenomen voor gevallen waar dialoog tekortschiet. De per convenant verschillende mechanismen komen in hoofdlijnen overeen. In de convenanten is geclausuleerd dat de partijen een stuurgroep en/of een klachten- en geschillencommissie instellen. De stuurgroep, die bestaat uit twee personen per soort partij - overheid, maatschappelijke organisatie en onderneming - en een door de partijen gezamenlijk gekozen onafhankelijke voorzitter, ziet namens de convenantpartijen toe op de naleving van de convenantafspraken, begeleidt de uitvoering daarvan en rapporteert jaarlijks over de voortgang. Indien partijen een geschil hebben, wordt dit besproken in de stuurgroep. Wanneer de stuurgroep niet unaniem tot een oplossing kan komen, kunnen partijen het geschil voorleggen aan een eventueel ingestelde klachten- en geschillencommissie, die een besluit zal nemen over de klacht of het geschil. ${ }^{112}$

Op het Convenant Duurzame Kleding en Textiel na is in de huidige convenanten voorts een clausule opgenomen die uitsluit dat het convenant in rechte kan worden afgedwongen. ${ }^{113}$ Indien tussen de betrokken partijen van het Convenant Duurzame Kleding en Textiel een geschil ontstaat over de niet- (of niet-tijdige) naleving van het besluit van de klachten- en geschillencommissie, dat bindend is, dan kan dat geschil door de betrokken partijen worden voorgelegd aan het Nederlands Arbitrage Instituut (NAI). ${ }^{114}$ Bij de beslechting van geschillen toetst het NAI marginaal of de betreffende partij het bindend advies van de klachten- en geschillencommissie wel of niet (tijdig) heeft opgevolgd. ${ }^{115}$

110 Kamerstukken II 2016/17, 30196, 480. Over het wetsvoorstel is reeds geconsulteerd, het zal in de nabije toekomst worden aangeboden aan de Raad van State, zie https://www. internetconsultatie.nl/ruimte_voor_duurzaamheidsinitiatieven/details en https://wetgevings kalender.overheid.nl/Regeling/WGK007665, beide geraadpleegd op 14 maart 2018.

111 IMVO-convenanten (SER-advies 14/04 van april 2014 aan de minister voor Buitenlandse Handel en Ontwikkelingssamenwerking en de minister van Economische Zaken), Den Haag: SER 2014, p. 58.

112 De convenanten Bevorderen Duurzaam Bosbeheer en Verantwoord Goud hebben geen klachtenen geschillencommissie, in tegenstelling tot de convenanten Duurzame Kleding en Textiel en Plantaardige Eiwitten.

113 Art. 14.11 Convenant Bancaire Sector; art. 13 Convenant Bevorderen Duurzaam Bosbeheer; art. 15 Convenant Plantaardige Eiwitten; art. 8.1 Convenant Verantwoord Goud.

114 Art. 1.3 Convenant Duurzame Kleding en Textiel.

115 Art. 1.3 Convenant Duurzame Kleding en Textiel. 
Afrondend, het is lastig in de startfase waarin IMVO-convenanten zich nog bevinden, te bezien in hoeverre zij leiden tot concrete resultaten. De resultaten van het eerste jaar Convenant Duurzame Kleding en Textiel zijn positief, maar laten tegelijkertijd zien dat er meer tijd en samenwerking nodig is om de wereldwijde textielsector te veranderen. ${ }^{116}$ In elk geval hebben de IMVO-convenanten de potentie om meerwaarde te bieden voor zowel degenen die mogelijk negatieve consequenties ondervinden door bepaalde ondernemingsactiviteiten als de ondernemingen die de risico's op negatieve impact van hun ondernemingsactiviteiten willen aanpakken. Daarnaast lijkt het niet onwaarschijnlijk dat de IMVO-convenanten voor een toename van de kansen voor de aangesloten ondernemingen zullen leiden op de internationale markten. Voor de toekomst geldt wel dat, om de impact van het IMVO-convenant verder te vergroten, het belangrijk is dat zo veel mogelijk partijen worden gestimuleerd zich aan te sluiten. Ook lijkt het nuttig om de uitwerking van de convenanten, maar ook de klacht- en geschilbeslechtingsmechanismen in de nabije toekomst te evalueren, om te bezien of deze in de praktijk (voldoende) effectief zijn.

\subsection{Transparantie}

Een laatste methode die wij bespreken en die in de praktijk steeds vaker wordt ingezet om MVO na te streven, is transparantie. Stakeholders, zoals aandeelhouders, consumenten, belangengroeperingen en overheden, verwachten in toenemende mate dat een onderneming transparant is over de prestaties op maatschappelijk vlak. Transparantie maakt het voor stakeholders mogelijk zich een beeld van deze prestaties te vormen en hierover de dialoog op gang te brengen. De afgelopen jaren beantwoorden ondernemingen steeds meer aan deze wens door middel van MVO-verslaggeving. Waar John Ruggie in 2000 rapporteerde dat minder dan 100 van de 80.000 multinationals wereldwijd rapporteerden over mensenrechten en milieu, is MVO-verslaggeving - zeker onder grote ondernemingen - inmiddels zo gebruikelijk dat meer dan $90 \%$ van de 250 grootste ondernemingen wereldwijd over MVO rapporteert. ${ }^{117}$ Onder andere de Nederlandse overheid moedigt dit sterk aan en probeert dit proces te stimuleren. Een voorbeeld daarvan is de Transparantiebenchmark, waarmee zij sinds 2004 jaarlijks de 500 grootste ondernemingen in Nederland rangschikt op basis van de mate waarin zij verantwoording afleggen in hun jaarverslagen over hun MVO-gerelateerde ondernemingsactiviteiten. ${ }^{118}$ Op internationaal niveau zijn duurzaam-

116 Zie de op 18 december 2017 gepubliceerde jaarrapportage, beschikbaar op https://www. imvoconvenanten.nl/kledingtextiel/news/2017/12/aanpak-problemen-kledingsector?sc_lang=nl, geraadpleegd op 15 maart 2018.

117 KPMG, The road ahead. The KPMG Survey of Corporate Responsibility Reporting 2017, beschikbaar op https://home.kpmg.com/content/dam/kpmg/campaigns/csr/pdf/CSR_Reporting_2017. pdf, geraadpleegd op 15 maart 2018.

118 Zie https://www.transparantiebenchmark.nl, geraadpleegd op 6 maart 2018; zie hierover ook S.N. Pabbruwe \& F. Streiff, 'Rapportageverplichtingen omtrent maatschappelijk verantwoord ondernemen: ontwikkelingen in wetgeving en praktijk’, MvO 2017, afl. 1-2, p. 46. 
heidsindices, zoals de Dow Jones Sustainability Index (DJSI), een voorbeeld van het zichtbaar maken van transparante ondernemingen. ${ }^{119}$

In enkele landen is voorts het initiatief genomen tot specifieke transparantiewetgeving. ${ }^{120}$ Zo is in Frankrijk met ingang van 27 maart 2017 MVO-due diligencewetgeving van kracht geworden. ${ }^{121}$ Hierdoor zijn ondernemingen met meer dan vijfduizend werknemers in Frankrijk of meer dan tienduizend wereldwijd verplicht om due diligence uit te voeren over hun gehele supply chain op het gebied van milieu, gezondheid, (kinder)arbeid en corruptie.122 De ondernemingen waarop de regeling van toepassing is, worden verplicht een due diligence-plan, ofwel een 'plan de vigilance', openbaar te maken en hun voortgang in jaarlijkse verslagen te publiceren. In het Verenigd Koninkrijk werd in 2015 de Modern Slavery Act 2015 (MSA) van kracht. Deze wet kent rapportageverplichtingen met betrekking tot arbeidsuitbuiting in de supply chain en is gericht op het terugdringen van 'moderne slavernij', waaronder slavernij, lijfeigenheid, dwangarbeid en mensenhandel moeten worden verstaan. Volgens de meeste commentatoren is art. 54 van deze wet, ook wel de 'Transparency in Supply Chains-clausule' genoemd, de belangrijkste bepaling. ${ }^{123}$ Op grond van dit artikel zijn commerciële organisaties verplicht jaarlijks een Slavery Statement te publiceren over de maatregelen die zij hebben genomen om moderne slavernij in de supply chain te voorkomen. Dit Slavery Statement kan onder meer informatie bevatten over (1) de structuur van de onderneming en de supply chains, (2) de interne beleidsrichtlijnen ten aanzien van moderne slavernij, (3) de aanwezigheid van due diligence-procedures, (4) plaatsen binnen de onderneming en de supply chain waar het risico op moderne slavernij aanwezig is en de voorzorgsmaatregelen die daar zijn getroffen, (5) de effectiviteit van het beleid, en (6) de educatie van personeel ten aanzien van moderne slavernij. ${ }^{124}$ Van belang hierbij is dat het Slavery Statement, ongeacht of dit de bovenstaande informatie bevat, door het bestuur moet worden goedgekeurd en door een bestuurder van de onderneming moet worden ondertekend. ${ }^{125}$ De MSA geldt ook voor Nederlandse ondernemingen die voldoen aan

119 Beschikbaar op www.sustainability-indices.com, geraadpleegd op 15 maart 2018.

120 In Nederland kan worden gewezen op het wetsvoorstel zorgplicht kinderarbeid, dat op 7 februari 2017 is aangenomen door de Tweede Kamer (Voorstel van wet van het lid Kuiken houdende de invoering van een zorgplicht ter voorkoming van de levering van goederen en diensten die met behulp van kinderarbeid tot stand zijn gekomen). Dit wetsvoorstel heeft volgens de initiatiefnemer als doelstelling 'ervoor te zorgen dat consumenten ervan uit kunnen gaan dat de goederen en diensten die zij op de Nederlandse markt kopen, verkocht worden door ondernemingen die binnen hun mogelijkheden redelijkerwijs er alles aan doen om te voorkomen dat hun producten en diensten tot stand komen met gebruikmaking van kinderarbeid'. Zie Kamerstukken I 2016/17, 34506, H.

121 Loi no 2017-399 du 27 mars 2017 relative au devoir de vigilance des sociétés mères et des entreprises donneuses d'ordre.

122 In Zwitserland wordt ook gewerkt aan een wetsvoorstel voor verplichte due diligence op MVOterrein.

123 P. Talibart, 'Modern slavery supply chain transparency and corporate governance', Bb 2017/80, p. 265.

124 Art. 54 (5) MSA.

125 Art. 54 (6) MSA. 
bepaalde criteria. Daarvan is sprake wanneer de onderneming (1) een commerciele organisatie is die (2) goederen of diensten levert en (3) een totale omzet heeft van minimaal $£ 36$ miljoen, en ten slotte (4) voldoet aan het criterium van 'carry[ing] on a business or part of a business' in het Verenigd Koninkrijk. ${ }^{126}$

Daarnaast kan worden gewezen op de Europese richtlijn inzake bekendmaking van niet-financiële informatie en informatie inzake diversiteit door bepaalde grote ondernemingen. ${ }^{127}$ De doelstelling van de richtlijn is om de 'samenhang en vergelijkbaarheid van de [door ondernemingen beschikbaar gestelde] niet-financiele informatie in de hele Unie te verbeteren'. ${ }^{128}$ De richtlijn verplicht grote organisaties van openbaar belang met een zetel in Europa om in een (bestuurs)verslag in principe te rapporteren over hoe zij omgaan met milieu-, sociale en personeelsaangelegenheden, eerbiediging van mensenrechten en bestrijding van corruptie en omkoping in de eigen onderneming en in de supply chain. ${ }^{129}$

De trend dat overheden ondernemingen verplichten de impact die hun ondernemingsactiviteiten op mensenrechten en andere MVO-thema's hebben te onderzoeken, sluit aan bij de due diligence-bepalingen uit internationale richtlijnen en gedragscodes, zoals de UN Guiding Principles en de OECD Guidelines. Het verschil is dat de nationale regelgeving niet vrijblijvend, maar bindend is. De wetgevingsinitiatieven gaan met dergelijke juridische verplichtingen verder dan de principes en gedragsregels die de internationale raamwerken voorschrijven. Daarbij verplichten deze initiatieven ondernemingen in toenemende mate zowel in hun eigen jurisdictie als in het buitenland op transparante wijze te rapporteren over MVO, waardoor ze hun stakeholders, klanten en het algemene publiek steeds meer inzicht geven over de manieren waarop zij invulling geven aan MVO in hun onderneming. Een opvallende gelijkenis van de verschillende wetgevingsinitiatieven is dat zij ondernemingen weliswaar bindende regels opleggen op het gebied van MVO, maar nauwelijks concrete verplichtingen opleggen tot het behalen van MVO-gerelateerde resultaten. ${ }^{130}$ MVO-rapportage vormt daarmee een juridisch minimum. Het is de vraag of de wetgevingsinitiatieven ondernemingen daadwerkelijk zullen aanzetten tot werkelijke en oprechte uitoefening van MVObeleid. Er zou daarom verder kunnen worden nagedacht over nadere uitwerking van deze verplichtingen alsmede sanctionering. In ieder geval is het een goede stap om ondernemingen bewust te maken van het feit dat MVO niet langer vrijwillig en vrijblijvend is. Daarbij is de kans aanwezig dat niet-juridische consequenties volgen wanneer een onderneming rapporteert nauwelijks of niets te doen aan

126 Zie ook A.L. Vytopil \& F.M. Verburg, 'Aansprakelijkheid in verband met "greenwashing"? Over oneerlijke handelspraktijken en wettelijk (on)verplichte MVO-verklaringen', TvOB 2017, afl. 2, p. 48.

127 Richtlijn 2014/95/EU van het Europees Parlement en de Raad van 22 oktober 2014 tot wijziging van Richtlijn 2013/34/EU met betrekking tot de bekendmaking van niet-financiële informatie en informatie inzake diversiteit door bepaalde grote ondernemingen en groepen.

128 Preambule 4 bij Richtlijn NFI.

129 Preambule 4 bij Richtlijn NFI.

130 Zie ook Zwalve-Erades 2015, p. 44. 
MVO, bijvoorbeeld doordat stakeholders de onderneming hier kritisch op aanspreken.

\section{Conclusie}

In deze bijdrage hebben wij de vraag beantwoord hoe MVO thans wordt gereguleerd, en voorts welke (juridische) instrumenten onder andere (kunnen) worden gehanteerd om te voldoen aan maatschappelijke verwachtingen ten aanzien van MVO. Ook is aan de orde gekomen in hoeverre de toepassing van deze instrumenten (juridisch) kan worden afgedwongen en of aanpassing vereist is. De conclusie is dat in de afgelopen twee decennia MVO een grote vlucht heeft genomen en er - ook in Nederland - steeds meer aandacht is voor MVO-initiatieven, zoals MVOgedragscodes, IMVO-convenanten en transparantie. Er is daarbij een voorzichtige trend zichtbaar in de transitie van vrijwillig over te nemen internationale soft lawinstrumenten naar steeds vaker verplicht toe te passen maatregelen of hard law. Voorts lijkt sprake te zijn van een overgang van een incidentgedreven beleid naar een meer structureel beleid van 'knowing and showing'. Voor ondernemingen is het ons inziens zaak om beleid na te streven dat is gericht op het zichtbaar maken en beperken van de negatieve impact die haar ondernemingsactiviteiten hebben op mens en milieu, en dit beleid onderdeel te maken van de bedrijfsvoering van de onderneming. Actief MVO-beleid werpt niet alleen zijn vruchten af op korte termijn, maar lijkt ook op lange termijn een verstandige keuze, immers:

'The leading companies are those that, through their core businesses, help society manage the world's major challenges. They have worked through the radical transformation of both internal corporate values and external market restructuring that has occurred in the four decades leading up to 2050, a transformation that many other companies have not survived but in which multitudes of new ones have been spawned. ${ }^{131}$

131 WBCSD, Vision 2050: The new agenda for business, 2010, p. 7, beschikbaar op www.wbcsd.org/ Overview/About-us/Vision2050/Resources/Vision-2050-The-new-agenda-for-business, geraadpleegd op 15 maart 2018. 